\title{
THE EXISTENCE OF THE VOLUNTEERS OF THE INDONESIAN HUMANITARIAN COMMITTEE IN DELIVERING INFORMATION ON PREVENTION AND HANDLING COVID-19
}

\section{EKSISTENSI RELAWAN KOMITE KEMANUSIAAN INDONESIA DALAM MENYAMPAIKAN INFORMASI PENCEGAHAN DAN PENANGANAN COVID-19}

\author{
Andre Avila, Rita Herlina \\ Universitas ARS \\ Email: andre.avila2209@gmail.com, rita.herlina@ars.ac.id
}

\begin{abstract}
How to Cite :
Avila .A, Herlina, R. (2020). THE EXISTENCE OF THE VOLUNTEERS OF THE INDONESIAN HUMANITARIAN COMMITTEE IN DELIVERING INFORMATION ON PREVENTION AND HANDLING COVID-19. SENGKUNI Journal- Social Sciences and Humanities. DOI: https://doi.org/10.37638/sengkuni.1.1.110-116
\end{abstract}

\section{ARTICLE HISTORY}

Received [11 Maret 2020]

Revised [13 April 2020]

Accepted [29 April 2020]

\section{KEYWORDS}

Existence, Volunteers, Submission of Information, Covid-19

This is an open access article under the $C C-B Y-S A$ license

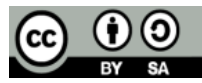

\begin{abstract}
ABSTRAK
Eksistensi relawan membantu pemerintah menyampaikan informasi yang tepat guna kepada masyarakat baik melalui media sosial atau terjun langsung ke lapangan melakukan komunikasi publik adalah yang melatarbelakangi penelitian ini, dengan tema Eksistensi Relawan Komite Kemanusiaan Indonesia dalam Menyampaikan Informasi Pencegahan dan Penanganan Covid-19. Penelitian ini bertujuan untuk memaparkan motivasi relawan, kegiatan relawan di lapangan dan bentuk pesan relawan di media sosial. Metodologi penelitian ini yaitu kualitatif yang dipaparkan secara deskriptif. Teknik pengumpulan data yaitu dengan wawancara dan analisis dokumen. Hasil dari penelitian ini menunjukkan eksistensi relawan Komite Kemanusiaan Indonesia sebagai garda terdepan dalam menyampaikan informasi pencegahan dan penanganan covid-19 kepada masyarakat Tangerang Selatan, dengan dilatarbelakangi motivasi rasa kepedulian kepada sesama sebagai upaya mengingatkan pentingnya pencegahan dan penanganan covid 19, dalam kegiatan relawan di lapangan yaitu menyebarkan flyer tentang pencegahan dan penangan Covid-19 melalui program pembagian sembako dan makanan, adapun bentuk pesan di media sosial tentang pencegahan dan penangan Covid-19 banyak dilakukan melalui media Facebook, Instagram, dan website dengan berbagai pesan dalam bentuk artikel, foto, status, dan pesan lainnya.
\end{abstract}

\section{ABSTRACT}

The existence of volunteers helping the government convey appropriate information to the public either through social media or plunging directly into the field of conducting public communication is the background of this research, with the theme of the Existence of the Volunteers of the Indonesian Humanitarian Committee in Delivering Information on Prevention and Handling Covid19. This study aims to describe the motivation of volunteers, volunteer activities in the field and forms of volunteer messages on social media. The methodology of this research is descriptive qualitative. Data collection techniques are by interview and document analysis. The results of this study indicate the existence of Indonesian Humanitarian Committee volunteers as the frontline in conveying information on prevention and handling of Covid-19 to the people of South Tangerang, motivated by caring for others as an effort to remind the importance of prevention and handling of Covid 19, in volunteer activities in the field, namely distributing flyers about prevention and handling of Covid-19 through food and food distribution programs, while the form of messages on social media about prevention and handling of Covid-19 is mostly done through Facebook, Instagram, website media, with various messages in the form of articles, photos, status, and messages the other.

\section{PENDAHULUAN}

Pengabdian masyarakat dalam situasi Covid-19 dapat dilakukan melalui peran relawan membantu pemerintah melakukan komunikasi publik. Banyak terjadi miss communication masyarakat akan beragam informasi mengenai cara penularan dan pencegahan hingga procedure pemerikasaan bagi yang dianggap orang dalam pemantauan (ODP), pasien dalam pengawasan (PDP), terduga menunjukkan gejala Corona (Suspect), dan positif atau negatif Covid-19 dan bahkan bagaimana kriteri oang tanpa gejala (OTG). 
Informasi yang valid dan jelas sangat dibutuhkan masyarakat agar tercapai kesuksesan bersama menuntaskan wabah Covid-19. Dalam kenyataannya di lapangan banyak masyarakat yang masih abai akan pentingnya menggunakan masker, sarung tangan, hingga pentingnya cuci tangan menggunakan sabun dan menyemprotkan handsanitizer pada tangan selekas memegang benda asing di luar.

Buruknya komunikasi publik pemerintah, diduga kuat menjadi penyebab abainya masyarakat akan waspada Virus Corona sejak dini. Pemerintah pusat dianggap sebagian besar publik telah lambat dan tumpang tindih dalam memutuskan aturan yang seringkali berbeda dengan pemerintah daerah menangani pencegahan dan penanganan Covid-19. Akibatnya munculah komunikasi krisis di masyarakat, yang menuntut pemerintah untuk segera menentukan sikap tegas membenahi kerancuan publik, dengan memberlakukan beragam strategi komunikasi dalam bentuk kebijakan publik yang pasti.

Virus Corona yang lazim disebut Covid-19 (Corona Virus Disease 2019) pertama kali ditemukan di kota Wuhan China pada akhir Desember 2019. Akhir Maret 2020 virus ini telah menyebar lebih dari 200 negara di dunia, meski sejak Januari 2020 belahan dunia sudah panik dengan Covid 19, Indonesia justru baru mengumumkan kasus pertamya ini pada 2 Maret 2020.

Virus Corona sangat cepat menular dan menyebar hampir ke seluruh dunia, termasuk Indonesia sebagai bagian negara yang terdampak Covid-19, akibat begitu dekatnya wilayah Indonesia dengan Cina, belum lagi adanya hubungan bilateral yang erat antara Indonesia-Cina dalam berbagai bidang kehidupan, menjadikan Indonesia sebagai salah satu negara yang ikut terpapar Virus Corona. Hal tersebut membuat beberapa negara di dunia menerapkan kebijakan berdasarkan standar WHO dengan memberlakukan lockdown atau pilihan lainnya seperti Social Distancing atau Phisical Distancing.

Dalam rangka pencegahan penyebaran Covid-19 di Indonesia, pemerintah memberlakukan kebijakan Pembatasan Sosial Berskala Besar (PSBB), dengan cara membatasi kegiatan serta melarang masyarakat untuk berpergian atau keluar masuk dari satu kota ke kota lain, dari satu daerah ke daerah lain, atau dari satu negara ke negara lain, kecuali dengan menunjukkan surat keterangan tugas dari instansi tertentu.

PSBB mulai diumumkan Pemerintah Pusat pada 31 Maret 2020, untuk diberlakukan April 2020 dan pelaksanaannya tergantung pada masing-masing kebijakan Pemerintah Kota atau Daerah setempat. Melalui PSBB, pemerintah menutup sejumlah akses kerumunan seperti Sekolah, Kampus, Kantor, Mall, Supermarket, Café, pembatasan Pasar, Toko-toko, tempat lbadah, dan lain sebagainya. Dipertengahan Mei 2020, pemerintah mulai memberlakukan pelonggaran atas PSBB.

Hingga kini upaya pencegahan penyebaran dan penanganan Covid-19 oleh pemerintah di Indonesia semakin masif bergerak, mulai dari Tingkat Daerah hingga Tingkat Pusat, semuanya bekerja bersama melawan Covid-19. Kontribusi masyarakat sangat dibutuhkan dalam kondisi genting seperti saat ini. Jalinan kerjasama pemerintah dengan warganya merupakan sumber kekuatan untuk mengehentikan penyebaran Covid-19.

Melihat korban Covid-19 yang setiap hari terus bertambah, menumbuhkan rasa peduli masyarakat melalui peran relawan untuk mengurangi dampak Covid-19. Pemerintah pun membuka perekrutan relawan dari seluruh kalangan masyarakat. Dilansir dari kompas.com, relawan itu sendiri berfokus membantu program-program komunikasi, edukasi, informasi dan layanan call center untuk masyarakat. (Prodjo, 2020). Dalam hal lainnya komunitas relawan sudah berdiri secara mandiri melalui kolektivitas kelompok dalam komunitas relawan tertentu.

Kegiatan relawan di tingkat Kabupaten atau Kota, bisa dilakukan dengan cara membantu pemerintah bekerjasama dengan segenap masyarakat, diantaranya dengan cara membantu penggalangan dana untuk kegiatan bakti sosial, pembagian alat pelindung diri (APD) rumah sakit, dan alat kesehatan lainnya seperti masker, handsanitizer, desinfektan, sabun cair. Selain itu penyebarluasan informasi tentang pencegahan dan penanganan Covid-19 penting dilakuakan agar tidak terjadinya kesimpangsiuran informasi, dan dapat meningkatkan kesadaran masyarakat untuk dapat lebih menjaga diri.

Peran relawan sangat dibutuhkan dalam membantu pemerintah guna menyebarluaskan informasi penting mengenai pencegahan dan penanganan Covid-19. Di era digital ini pun, tidak sedikit relawan yang menggunakan media sosial untuk menyampaikan kegiatan dan kepedulian 
sosialnya. Sehingga kegiatan kerelawanan maupun sosok relawannya menjadi kekinian dan mampu menarik minat masyarakat untuk berpartisipasi baik secara moril maupun materiil.

Di setiap daerah banyak bermunculan komunitas relawan yang tumbuh subur bersatu dalam tujuan untuk membantu meringankan tugas pemerintah dalam upaya pencegahan dan penanganan Covid-19. Seperti yang dilakukan Komite Kemanusiaan Indonesia (KKI) yang berlevel Internasional, berada di Kota Tangerang Selatan, Provinsi Banten. KKI sudah berdiri sejak tahun 2014. Setelah adanya musibah Tsunami Aceh pada tahun 2006, organisasi ini terbentuk karena banyaknya penggiat sosial yang tergabung menjadi relawan. Hingga saat ini KKI menjadi sarana berkumpulkan para relawan yang ingin tetap konsisten menjadi garda terdepan membantu masyarakat dalam menangani setiap musibah.

Dalam eksistensinya di masa pandemi ini, sejak munculnya wabah Covid-19 KKI dengan sigap turut serta berkontribusi melakukan berbagai kegiatan dengan turun langsung membantu masyarakat. Melalui visi misinya untuk selalu menolong kepada sesama, KKI berupaya menggalang dana untuk tujuan bakti sosial kepada warga yang terdampak. Upaya edukasi kepada masyarakat rutin dilakukan melalui komunikasi publik.

Berdasarkan konteks penelitian yang telah penulis uraikan di atas, penulis tertarik untuk melakukan penelitian dengan mengambil judul "Eksistensi Relawan KKI dalam Menyampaikan Informasi Pencegahan dan Penanganan Covid-19".

\section{TINJAUAN TEORITIS}

\section{Kajian Literatur}

Volunteering (kerelawanan) adalah panggilan hati atau jiwa seseorang untuk menolong siapa saja yang terkena bencana dengan ikhlas tanpa mengharapkan imbalan atau bayaran apapun. Firman Venayaksa mengatakan menjadi relawan itu panggilan nurani, kita mesti berbuat untuk lingkungan kita, untuk sesama kita, menjadi relawan itu menjadi pelayan, sebaik-baiknya kita adalah yang paling bermanfaat bagi sesama. (Venayaksa, 2011)

Dilansir dari Gadjah Mada Journal of Psychology bahwa tolong menolong dalam konteks penanganan bencana alam seringkali melibatkan banyak orang. Beberapa upaya dapat dilakukan untuk menolong para korban bencana, yaitu bisa melalui penyaluran donasi, kebutuhan-kebutuhan para korban, atau melalui tenaga dengan turun secara langsung terlibat di lapangan membantu penanganan pasca bencana alam. Mereka biasanya tergabung dalam komunitas yang aktif dalam kegiatan penanggulangan bencana alam. Masyarakat umum menyebut individu-individu tadi sebagai relawan. (Utomo \& Minza, 2018)

Badan Nasional Penanggulangan Bencana (BNPB, 2014) menjelaskan tentang pedoman relawan penanggulangan bencana, relawan penanggulangan bencana yang selanjutnya disebut relawan adalah seorang atau sekelompok orang yang memiliki kemampuan dan kepedulian untuk bekerja secara sukarela dan ikhlas dalam upaya penanggulangan bencana.

Relawan dalam penelitian ini memiliki peran untuk membantu pemerintah mensosialisasikan program pencegahan dan penangan Covid 19. Relawan dengan sukarela menjadi garda terdepan untuk terjun ke masyarakat membantu masyarakat yang kesusahan.Fungsi relawan yang semula membantu masyarakat akibat terkena bencana alam, namun dalam kondisi pandemik ini fungsinya bergeser untuk membantu pemerintah agar masyarakat dapat memiliki kesadaran akan pentingnya informasi yang tepat dalam pencegahan dan penanganan covid 19, melalui komunikasi publik.

Menurut Richard West Komunikasi Publik adalah komunikasi yang dilakukan di depan banyak orang. Dalam komunikasi publik pesan yang disampaikan dapat berupa suatu informasi, ajakan, gagasan. Sarananya, bisa media massa, bisa pula melalui orasi pada rapat umum atau aksi demonstrasi, blog, situs jejaring sosial, kolom komentar di website/blog, e-mail, milis, SMS, surat, surat pembaca, reklame, spanduk, atau apa pun yang bisa menjangkau publik. Yang pasti, Komunikasi Publik memerlukan keterampilan komunikasi lisan dan tulisan agar pesan dapat disampaikan secara efektif dan efisien. Komunikasi publik sering juga disebut dengan komunikasi massa. Namun, komunikasi publik memiliki makna yang lebih luas dibanding dengan komunikasi 
massa. Komunikasi massa merupakan komunikasi yang lebih spesifik, yaitu suatu komunikasi yang menggunakan suatu media dalam menyampaikan pesannya. (West, 2008)

Eksistensi adalah hal berada, keberadan, kehadiran yang mengandung unsur bertahan.(Kamus Besar Bahasa Indonesia, 2008). Zaenal Abidin menambahkan eksistensi sebagai suatu proses yang dinamis, suatu, menjadi atau mengada. Ini sesuai dengan asal kata eksistensi itu sendiri, yakni exsistere, yang artinya keluar dari, melampaui atau mengatasi. Jadi eksistensi tidak bersifat kaku dan terhenti, melainkan lentur atau kenyal dan mengalami perkembangan atau sebaliknya kemunduran, tergantung pada kemampuan dalam mengaktualisasikan potensi-potensinya.(Abidin, 2007)

Eksistensi relawan KKI dapat terlihat keberadannya melalui beragam aktivitas sosial di masyarakat dalam agenda yang secara rutin dilaksanakan. Seluruh kegiatannya ditunjukkan melalui media sosial sebagai ajang pembuktian atas eksitensi diri relawan KKI.

\section{Teori Fenomenologi Alfred Schutz}

Dalam Kuswarno dikatakan Schutz, bahwa konsep "sosial" didefinisikan sebagi hubungan antara dua atau lebih orang dan konsep "tindakan" didefinisikan sebagai perilaku yang membentuk makna subjektif (subjective meaning).

Dalam menggambarkan tujuan suatu tindakan seseorang cukup kompleks, Scutz menyebut in the future perfect tense. Sementara itu, suatu tindakan dapat berupa "tindakan yang telah lengkap (the complete act). Tindakan adalah sebuah makna yang rumit atau makna kontekstual, oleh karena itu, untuk menggambarkan seluruh tindakan seseorang perlu diberi fase. Schutz mengusulkan fase yang bernama in order to motive (motif supaya) yang merujuk pada masa yang akan datang. Kemudian tindakan because motif (motif karena), yang merujuk pada masa lalu. (Kuswarno, 2013)

Relawan KKI yang aktif berperan menyebarkan informasi publik tentang pencegahan dan penanganan Covid 19 pada konteks fenomenologi merupakan seseorang yang melakukan tindakan sosial dengan seseorang lainnya yang memiliki makna intersubjektif yang sama. Para relawan KKI dilandasi oleh bermacam motif yang mendasari mengikuti dengan tujuan akhir informasi sampai pada masyarakat, dan masyarakat dapat lebih waspada serta dapat tertanam dalam pikiran dan tindakan bahwa mencegah jauh lebih baik daripada mengobati.

\section{METODE PENELITIAN}

Penelitian ini menggunakan desain penelitian kualitatif. dipaparkan secara deskriptif, dimana penulis menjelaskan berbagai temuan secara sistematis dan menghubungkan temuan tersebut dengan teori-teori relevan (Creswell, 2008). yang bertujuan untuk mengkaji informasi yang didapat melalui Relawan Komite Kemanusiaan Indonesa Kota Tangerang Selatan dalam Penyampaian informasi Pencegahan dan Penanganan Covid-19. Penulis melakukan komparasi antara literatur dengan pengetahuan. Teknik pengumpulan data melalui dua cara yaitu menggunakan wawancara dan analisis dokumen. Dalam penelitian ini sumber informannya terdiri dari beberapa Relawan dari komunitas Komite Kemanusiaan Indonesa KKI, berlokasi di Kota Tangerang Selatan.

\section{PEMBAHASAN}

\section{Motivasi Relawan KKI dalam Menyebarluaskan Informasi Pencegahan dan Penanganan Covid-19}

Pandemi Covid 19 adalah bencana nonalam yang menurut UU No.24 Tahun 2007 tentang penanggulanan bencana, bencana nonalam adalah bencana yang diakibatkan oleh peristiwa atau rangkaian peristiwa nonalam yang antaralain berupa gagal teknologi, gagal modernisasi, epidemi dan wabah penyakit. Lain halnya Who menyebut bencana sebagai kejadian yang menyebabkan kerusakan, gangguan ekologis, hilangnya nyawa manusia atau memburuknya derajat kesehatan atau pelayanan kesehatan pada skala tertentu yang memerlukan respon dari luar masyarakat atau wilayah yang terkena. (Arifin, 2020). Dengan demikian bencana itu tidak hanya tentang kerusakan 
alam, melainkan segala sesuatu yang menyebabkan kerusakan hidup manusia adalah merupakan bencana.

Relawan komite kemanusiaan (KKI) adalah orang-orang yang terbiasa tergabung dalam menanggulangi berbagai bencana alam. Relawan KKI menganggap pandemi Covid 19 ini adalah sebagai bencana yang memerlukan penangan khusus dari pemerintah serta kerjasama dari masyarakat. Demi membantu program pemerintah tersebut, relawan $\mathrm{KKI}$ turun langsung berkontribusi dalam berbagai kegiatan bakti sosial dan komunikasi publik, baik melalui media sosial maupun tatap muka dengan turun langsung ke lapangan.

Ditemukan motivasi relawan KKI menyebarluaskan informasi pencegahan dan penanganan covid-19 berdasarkan because motif (motif karena) yang merujuk pada masa lalu, dan in order to motive (motif supaya) yang merujuk pada masa yang akan datang. Because motif menunjukkan alasan karena kemanusiaan untuk membantu banyak orang, dan sebagai rasa kepedulian kepada sesama. Sementara motivasi yang berasal dari in order to motive adalah sebagai upaya mengingatkan masyarakat akan pentingnya informasi pencegahan dan penanganan covid 19 dengan motivasi supaya resiko penyebarluasan virus bisa diminimalisir, dengan cara meningkatkan kesadaran masyarakat akan pentingnya pencegahan melalui berbagai macam usaha seperti menjaga jarak, menggunakan masker, dan selalu mencuci tangan.

Relawan adalah sekelompok orang yang bergiat membantu dan menolong sesama secara sukarela, tanpa ada imbalan. Dalam aktivitasnya operasioanal kegiatan KKI biasanya bergantung pada bantuan dari donator. Meskipun di masa pandemi Covid-19 ini terjadi penurunan donasi, akibat para donatur yang banyak terkena dampak ekonomi. Tidaklah menyurutkan semangat relawan KKI untuk tetap menjalankan visi dan misinya menjadi garda terdepan memberikan bantuan kepada masyarakat yang tekena dampak bencana.

\section{Kegiatan Relawan KKI di Lapangan dalam Menyebarluaskan Informasi Pencegahan dan Penanganan Covid-19}

Kegiatan relawan KKI dalam menyampaikan informasi pencegahan dan penanganan Covid19 di lapangan, adalah dengan membagikan flyer yang berisikan informasi pencegahan dan penanganan covid-19. Pelaksanan pembagian flyer dilakukan berbarengan dengan program pembagian sembako dan program pembagian makanan.

Kegiatan pembagian sembako oleh relawan KKI kepada masyarakat, dilakukan melalui Program Bantuan Tulang Punggung Keluarga Terdampak Covid 19, lewat donasi yang telah dikumpulkan dari para donator. Relawan KKI mendistribusikan sembako kepada warga yang terdampak di Kota Tangerang Selatan, terutama diberikan kepada para tulang punggung keluarga.

Kegiatan lainnya dilakukan di bulan Suci Ramadhan pada April hingga Mei 2020. Relawan KKI rutin membagikan makanan buka puasa gratis kepada warga yang yang terdampak, melalui Program Iftor Ramadhan 2020-1441 H. Hampir setiap hari sebanyak kurang lebih 250 box relawan KKI membagikan makanan untuk buka puasa. Pembagian makanan dilakukan dengan turun langsung bertemu masyarakat yang membutuhkan, baik dibagikan di jalanan maupun diantar langsung ke rumah-rumah. 


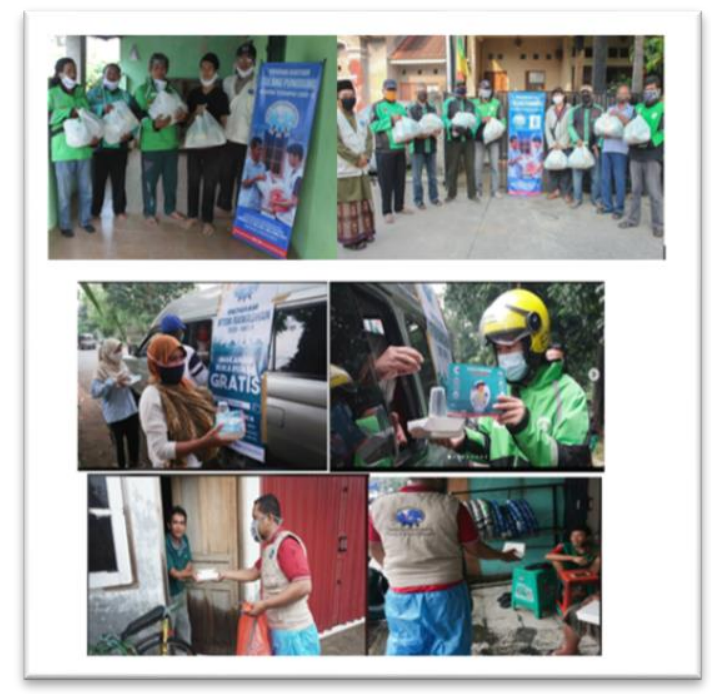

Sumber : Facebook KKI (2020)

Gambar 1. Kegiatan KKI di Lapangan

Ketika bertatap muka langsung dengan masyarakat, relawan KKI tentu menggunakan standar protokoler Covid-19, dengan tetap menjaga jarak dan menggunakan masker. Dalam kegiatan tersebut relawan KKI berupaya menyampaikan pesan untuk tetap waspada terhadap virus corona melalui flyer, sebagai edukasi kepada warga tentang bagaimana caranya mencegah dan menangani Covid 19 berdasarkan anjuran pemerintah dalam hal ini Kementrian Kesehatan. Dengan komunikasi tatap muka secara langsung, diharapkan masyarakat akan lebih memahami pesan agar lebih waspada terhadap rentannya penularan virus tersebut.

Kegiatan KKI dalam menyebarkan informasi tentang pencegahan dan penangan Covid-19, melalui flyer yang dibagikan dalam setiap kegiatan bakti sosial selalu mendapatkan respon positif. Relawan KKI berupaya menggalang dana dan membagikan bantuan dalam bentuk sembako, APD, makanan dan lain sebagainya kepada masyarakat yang terdampak Covid-19. Kegiatan ini mendapat sambutan yang luar biasa melalui kerjasama dengan para donator yang terbina hingga saat ini. Respon dari masyarakat yang menerima bantuan dari kegiatan ini sangat positif, di mana mereka merasa terbantukan atas kegiatan relawan KKI di Kota Tangerang Selatan.

\section{Bentuk Pesan Relawan KKI di Media Sosial dalam Pencegahan dan Penanganan Covid-19}

Relawan KKI dalam eksistensinya menyampaikan informasi tentang pencegahan dan penanganan Covid-19 salah satunya melalui media sosial. KKI sendiri memiliki situs website organisasi yang berisi beranda, profil, berita, program, foto kegiatan, donasi, dan kontak. Dalam website tersebut masyarakat Indonesia bahkan dunia dapat melihat aktivitas $\mathrm{KKI}$ dan berinteraksi melalui kontak yang tersedia. Selain itu KKI juga memanfaatkan media sosial sebagai media interaksi terkini, yaitu Facebook dan Instagram, kedua media tersebut dianggap lebih familiar, mudah diakses kapanpun dan dimanapun. 


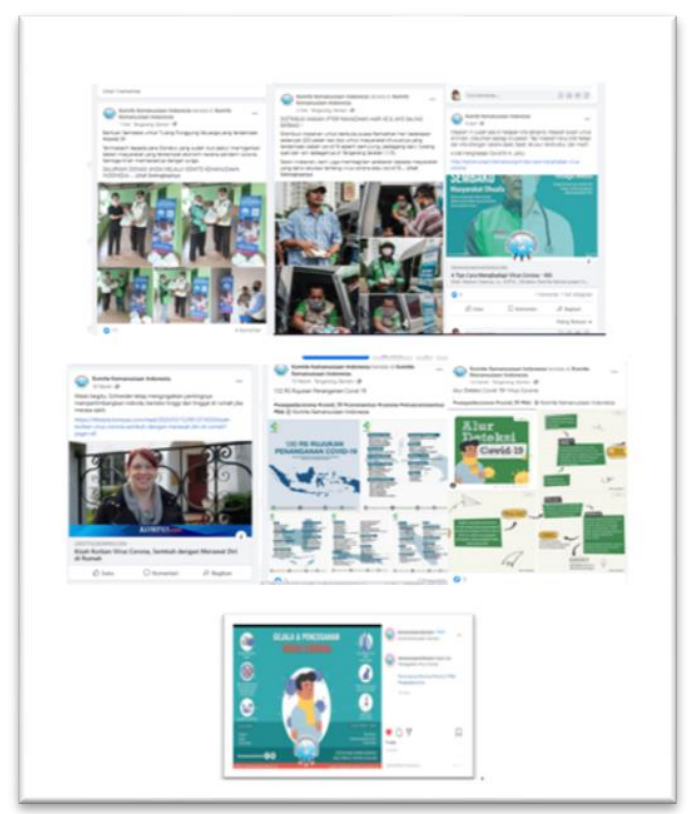

Sumber: FB dan IG KKI (2020)

Gambar 2. Pesan KKI di Medsos

Melalui Facebook, Instagram dan website, informasi tentang Covid 19 mulai intens disampaikan sejak Maret 2020. Dari beberapa pesan yang disampaikan di media sosial pada umumnya menyampaikan Artikel tentang Covid-19, Foto kegiatan relawan KKI pada saat berbagi, Foto tentang Informasi Rumah Sakit rujukan Covid, Foto tentang data Dokter yang meninggal akibat Covid-19, Foto untuk mencegah dan menangani Covid-19, Foto dan status ajakan untuk berdonasi kepada korban Covid-19, dan video siaran langsung pada saat berbagi.

Pesan ajakan yang sering disampaikan melalui media sosial adalah ajakan untuk selalu berbagi melalui donasi yang akan disalurakan kepada masyarakat khususnya yang terdampak ekonomi karna wabah covid-19, donasi juga diperuntukkan untuk memenuhi kebutuhan APD Rumah Sakit. Selain itu pesan ajakan juga disampaikan dalam statusnya tentang bagimana gejala dan pencegahan Virus Corona merujuk dari Kementrian Kesehatan yaitu dengan Menjaga Kebersihan Tangan, Hindari Kontak Langsung dengan Siapapun yang Menunjukkan Gejala Terinveksi Corona, Konsumsi Gizi Seimbang, Olahraga dan Cukup Istirahat, Hindari Kontak Langsung dengan Hewan, Tutup Hidung dan Mulut Ketika Bersin dan Batuk.

Bentuk pesan relawan KKI di media sosial menunjukkan adanya informasi tentang pencegahan dan penanganan covid-19, melalui beragam kiriman informasi dalam setiap kesempatan melaksanakan berbagai kegiatan, yang selalu up-date setiap waktunya.

\section{KESIMPUAN DAN SARAN}

Berdasarkan pembahasan yang telah diteliti diatas, dapat disimpulkan bahwa motivasi relawan $\mathrm{KKI}$ menyebarluaskan informasi pencegahan dan penanganan covid-19 berdasarkan Because motif menunjukkan alasan karena kemanusiaan untuk membantu banyak orang, dan sebagai rasa kepedulian kepada sesama. Sementara motivasi yang berasal dari in order to motive adalah sebagai upaya mengingatkan masyarakat akan pentingnya informasi pencegahan dan penanganan covid-19 dengan motivasi supaya resiko penyebarluasan virus bisa diminimalisir, dengan cara meningkatkan kesadaran masyarakat akan pentingnya pencegahan dan penangan Covid-19.

Kegiatan relawan KKI dalam menyampaikan informasi pencegahan dan penanganan Covid19 di lapangan, adalah dengan membagikan flyer yang berisikan informasi pencegahan dan penanganan covid-19. Pelaksanan pembagian flyer dilakukan berbarengan dengan program pembagian sembako dan program pembagian makanan. 
Eksistensi relawan $\mathrm{KKI}$ secara massif dan berkesinambungan ditunjukkan melalui rutinitas relawan KKI meyampaian informasi tentang pencegahan dan penanganan covid-19 di media sosial baik Facebook, Instagram dan website, dengan berbagai pesan dalam bentuk artikel, foto, status, dan pesan lainnya.

Beragam tanggapan positif menunjukkan keberadaan relawan $\mathrm{KKI}$ adalah patut mendapatkan apresiasi dan dukungan penuh karena mampu menjadi garda terdepan dalam melayani masyarakat.

Siapapun bisa menjadi relawan dengan turun tangan kepada masyarakat. Menjadi relawan bisa melalui sumbangsih tenaga, materil maupun moril. Perlu kiranya kesadaran masyarakat akan pentingnya pencegahan dan penanganan Covid-19 dengan tetap menjaga protokoler kesehatan.

\section{DAFTAR PUSTAKA}

Abidin, Z. (2007). Analisis Eksistensial:Sebuah Pendekatan Alternatif untuk Psikologi dan Psikiatri. Retrieved from http://opac.unila.ac.id/ucs/index.php?p=show_detail\&id=5155

Arifin, D. (2020). Status Keadaan Tertentu Darurat Bencana Wabah Penyakit Akibat Virus Corona di Indonesia. In bnpb.go.id. Retrieved from https://bnpb.go.id/berita/status-keadaan-tertentudarurat-bencana-wabah-penyakit-akibat-virus-corona-di-indonesia-(24 Juli 2020)

BNPB. (2014). Penanggulangan Bencana Pedoman. Berita Negara Republik Indonesia, (1422), 8 35. Retrieved from http://ditjenpp.kemenkumham.go.id/arsip/bn/2014/bn1422-2014.pdf

Kamus Besar Bahasa Indonesia. (2008). Jakarta: Gramedia Pustaka Utama.

Kuswarno, E. (2013). Metode Penelitian Komunikasi : Fenomenologi. Bandung: Widjaya Padjajaran. Prodjo, W. A. (2020). Mahasiwa Siap Jadi Relawan Penanganan Corona. In kompas.com. Retrieved from https://www.kompas.com/edu/read/2020/03/26/090000771/15.000mahasiswa-siap-jadi-relawan-penanganan-corona.(23 Juli 2020)

Rudianto. (2020). Krisis Komunikasi dalam Pandemi Covid-19 (F. Junaedi, ed.). Yogyakarta: Buku Litera.

Utomo, M. H., \& Minza, W. M. (2018). Perilaku Menolong Relawan Spontan Bencana Alam. Gadjah Mada Journal of Psychology (GamaJoP), 2(1), 48. https://doi.org/10.22146/gamajop.31871

Venayaksa, L. dkk. (2011). Relawan Dunia. Jakarta: Kepustakaan Populer Gramedia.

West, R. (2008). Pengantar Teori Komunikasi. Jakarta: Salemba Humanika. 